\title{
Predators and Parasitoids of Pine Processionary Moth (Thaumetopoea wilkinsoni Tams) in Western Mediterranean Region in Turkey
}

\author{
İsmail Erkaya*1
}

\begin{abstract}
The pine processionary moth, Thaumetopoea wilkinsoni Tams, 1924 (Lepidoptera: Notodontidae) is the most important defoliator pest of pine forests in the Mediterranean Basin and Turkey. Natural enemies of the pine processionary moth are various species of predators and parasitoids. In this study, field studies were performed in nine study areas which were chosen from four provinces (Isparta, Burdur, Antalya, Muğla) in the Western Mediterranean Region of Turkey to determine the potential predators, larva and egg parasitoids of pine processionary moth. Wintering nests and egg batches of the pine processionary caterpillars were sampled from selected study stations throughout 2018. Calosoma sycophanta (L.) and Forficula smyrnensis Serville were determined as predator species and Phryxe caudata (Róndani), Trichogramma sp., Ooencyrtus pityocampae (Mercet) and Anastatus bifasciatus (Geoffroy) were determined as parasitoids. Forficula smyrnensis is recoreded for the first time as a predator of T. wilkinsoni. Results may contribute to the literature on ecology, forestry studies and biological control efforts
\end{abstract}

Keywords: Forficula smyrnensis, parasitoid, pine processionary moth, Thaumetopoea wilkinsoni, western mediterranean region.
${ }^{1}$ Address: Suleyman Demirel Üniversity, Faculty of Arts and Sciences, Department of Biology, 32260, Isparta, Turkey.
*Corresponding author: ismailerkaya@sdu.edu.tr
Citation: Erkaya, I. (2020). Predators and Parasitoids of Pine Processionary Moth (Thaumetopoea wilkinsoni Tams) in Western Mediterranean Region in Turkey. Bilge International Journal of Science and Technology Research, 4 (1): 7-13.

\section{INTRODUCTION}

Pine Processionary Moth (PPM), Thaumetopoea wilkinsoni Tams, (Lepidoptera: Notodontidae) is the most important leaf defoilator pest of Southwest Europe, North Africa and the Near East (Battisti et al., 2000). It is the common pest in the Mediterranean Basin and in southern, western and northern parts of Turkey. Pine processionary larvae feed with pine needles in forest ecosystems, weaken the pines and make them vulnerable to secondary pests. Although PPM causes damage to other pine species, its main host is Turkish red pine (Pinus brutia Ten.) and its development on each pine species varies (Hodar et al., 2002). In addition to causing serious economic and ecological losses, the setae of the larvae cause allergic reactions and respiratory disorders such as asthma in humans and mammals (Ziprkowski and Roland, 1966; Lamy, 1990). Two species distributed in Turkey are Thaumetopoea pityocampa (Den. \& Schiff.) and T. wilkinsoni (Barbaro and Battisti, 2011). Thaumetopoea wilkinsoni is mostly found in pine forests in the south, west and north of Anatolia, while T. pityocampa generally occurs in Thrace and northwestern Anatolia, and there is a potential hybrid zone of these two twin species in this region (İpekdal et al., 2015).
In the studies to determine the parasitoids using PPM as a host, nine species of egg parasitoid, all belonging to Hymenoptera, were identified. The most common two egg parasitoids are generalist Ooencyrtus pityocampae (Merc.) (Hymenoptera, Encyrtidae) and host specific Baryscapus servadeii (Dom.) (Hym., Eulophidae). Anastatus bifasciatus (Fonsc.) (Hym., Eupelmidae), Trichogramma embryophagum (Hbg.) (Hym., Trichogrammatidae), Trichogramma dendrolimi Matsumura (Hym., Trichogrammatidae), Baryscapus transversalis Graham (Hym., Eulophidae), Pediobius bruchicida (Rondani) (Hym., Eulophidae), Eupelmus (Macroneura) seculata (Ferrière) (Hym., Eulophidae) and Eupelmus (Macroneura) vesicularis (Retzius) (Hym., Eulophidae) are parasitoid species with a lower frequency (Tsankov, 1990; Tsankov et al., 1999; Öztemiz et al., 2013; Battisti et al., 2015).

The known larva parasitoids are Phryxe caudata (Rondani) (Diptera, Tachinidae), Compsilura concinnata (Meigen) (Dipt., Tachinidae), Exorista segregata (Rondani) (Dipt., Tachinidae), Erigorgus femorator Aubert (Hym., Ichneumonidae), Cotesia vestalis (Haliday) (Hym., Braconidae), Pteromalus chrysos Walker (Hym., 
Chalcididae) and Dibrachys lignicola Graham (Hym., Chalcididae) belonging to Hymenoptera and Diptera (Battisti et al., 2015). Pupa parasitoids are determined in the previous studies as Villa brunnea Beck. (Dipt., Bombyliidae), Coelichneumon rudis (Fonscolombe) (Hym., Ichneumonidae) and Conomorium pityocampae Graham (Hym., Pteromalidae) (Battisti et al., 2015).

The known natural predators of the PPM include some birds, amphibians, reptiles, spiders and predator insects. Upupa epops and Clamator glandarius (Aves), Bufo viridis and Hyla arborea (Amphibia) Agamia stellio (Reptilia), Thomisus citrinellus (Arachnida), Carabus graecus, Calosoma sycophanta, Chrysoperla carnea, Coccinella septempunctata, Chilocorus bipustulatus, Synbarmonia conglobata, Forficula auricularia, Formica rufa, Monomorium dentiger, M. gracillimum, Ephippiger ephippiger, Dermestes lardarius, Sphodromantis viridis, Labidura riparia and Tettigonidae species of Insecta are predators of PPM (Mirchev and Tsankov, 2005). Pathogens include a variety of viruses, bacteria and fungi (Battisti et al., 2015). In the Mediterranean basin, extensive control studies are conducted with vertebrate and invertebrate predators, pathogens such as Bacillus thuringiensis kurstaki and pesticides such as insect growth inhibitors in the control against PPM (Barbaro and Battisti, 2011). However, it is stated that these predators and pathogens do not have a significant effect on population control except epidemic periods (Way et al., 1999). Pesticides have various damages in biological control. Pesticides can also have adverse effects on non-target organisms, target natural predators of the pest and cause phytophagous insect to develop resistance (Jansen and Sabelis, 1995). For these reasons, parasitoid species should be preferred in biological control. Parasitoids do not have the disadvantages of pesticides and have an important role in controlling harmful herbivore insect populations (Lewis et al., 1997; Stiling and Cornelissen 2005). In fact, it was determined that egg parasitoids increase PPM mortality by $72 \%$ (Mirchev et al., 2004).

In this study, it is aimed to determine the potential parasitoids and predators of $T$. wilkinsoni that uses Turkish red pines as hosts in the western Mediterranean region of Turkey.

\section{MATERIALS AND METHODS}

Nine study stations selected from the Western Mediterranean region were visited during 2018 in order to collect samples from PPM (Thaumetopoea wilkinsoni Tams), taking into account the density of red pine (Pinus brutia Ten.). The stations were selected from three different elevation intervals (0-100 m, 400-650 m and 900-1100 m) within four different provinces (Isparta, Burdur, Antalya, and Mugla). Map of nine selcted study stations are shown in Figure 1.

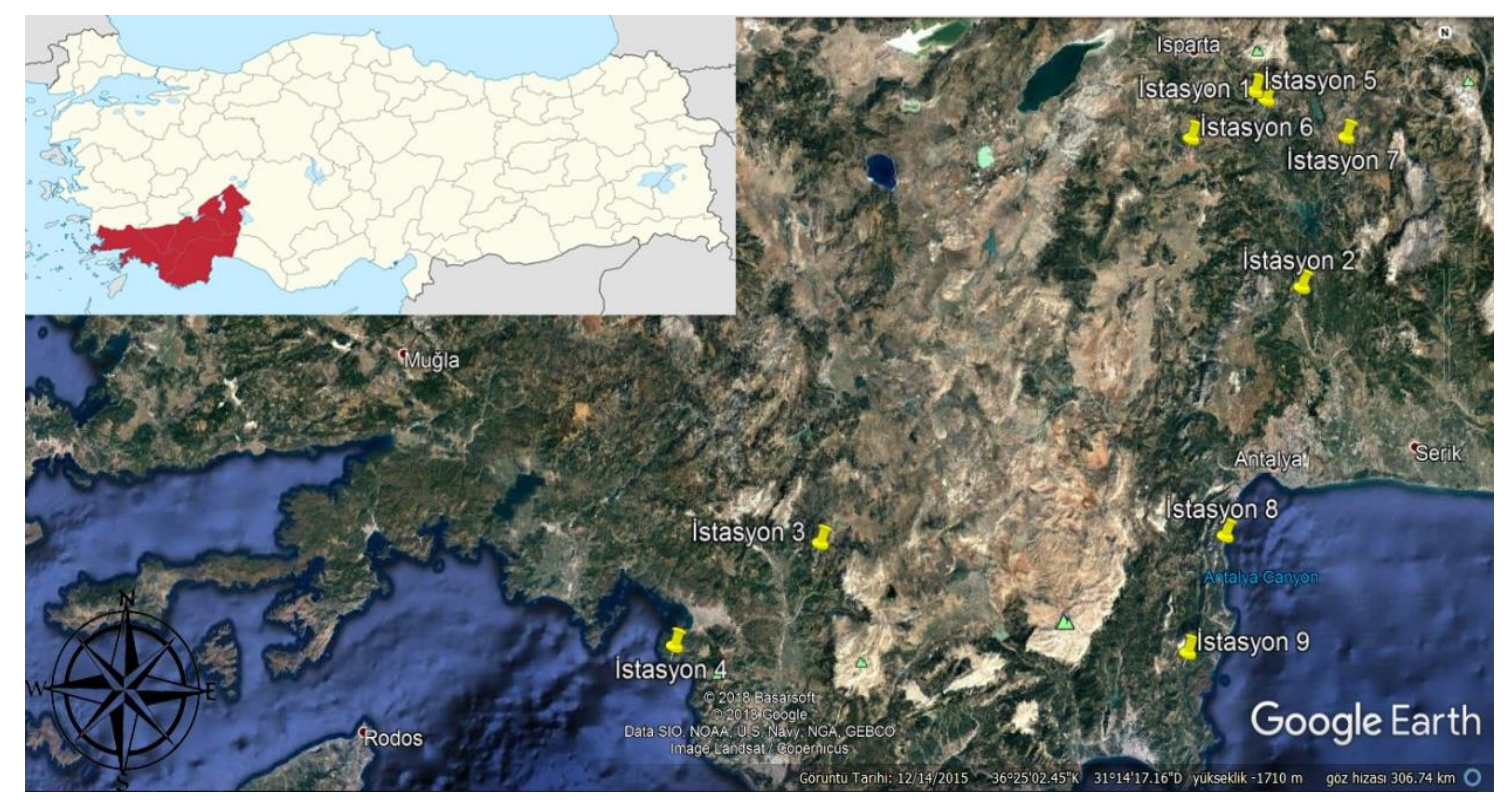

Figure 1. Satellite image of study stations. 
Sampling date, localities, coordinates, altitude and area characteristics of nine study stations are shown in Table 1.

Table 1. Localities and area characteristics of study stations.

\begin{tabular}{|c|c|c|c|c|}
\hline St.No & $\begin{array}{l}\text { Sampling } \\
\text { Date }\end{array}$ & Location & $\begin{array}{l}\text { Coordinates } \\
\text { and Altitude }\end{array}$ & Area Characteristics \\
\hline 1 & 18.02.2018 & $\begin{array}{l}\text { Isparta- } \\
\text { Antalya } \\
\text { highway } \\
\text { 30th km }\end{array}$ & $\begin{array}{l}37^{\circ} 37^{\prime} 29^{\prime \prime} \mathrm{N} \\
30^{\circ} 43^{\prime} 58^{\prime \prime} \mathrm{E} \\
600-630 \mathrm{~m}\end{array}$ & Near highway, pine forest \\
\hline 2 & 18.02.2018 & $\begin{array}{l}\text { Isparta- } \\
\text { Antalya } \\
\text { highway } \\
\text { 80th km }\end{array}$ & $\begin{array}{l}37^{\circ} 13^{\prime} 53^{\prime}, \mathrm{N} \\
30^{\circ} 48^{\prime} 7^{\prime}, \mathrm{E} \\
90-100 \mathrm{~m}\end{array}$ & Near highway, pine forest \\
\hline 3 & 10.03.2018 & $\begin{array}{l}\text { Burdur- } \\
\text { Fethiye } \\
\text { highway }\end{array}$ & $\begin{array}{l}36^{\circ} 45^{\prime} 36^{\prime \prime} \mathrm{N} \\
29^{\circ} 27^{\prime} 31^{\prime \prime} \mathrm{E} \\
980 \mathrm{~m}\end{array}$ & $\begin{array}{l}\text { Short pines on highway } \\
\text { edge, clear area }\end{array}$ \\
\hline 4 & 10.03.2018 & $\begin{array}{l}\text { Fethiye, } \\
\text { Gemiler }\end{array}$ & $\begin{array}{l}36^{\circ} 33^{\prime} 49^{\prime \prime} \mathrm{N} \\
29^{\circ} 3^{\prime} 6^{\prime \prime} \mathrm{E} \\
0-70 \mathrm{~m}\end{array}$ & $\begin{array}{l}\text { Sloping terrain, dense pine } \\
\text { forest }\end{array}$ \\
\hline 5 & 23.03.2018 & $\begin{array}{l}\text { Burdur, } \\
\text { Ağlasun }\end{array}$ & $\begin{array}{l}37^{\circ} 38^{\prime} 35^{\prime}, \mathrm{N} \\
30^{\circ} 42^{\prime} 7^{\prime}, \mathrm{E} \\
1020 \mathrm{~m}\end{array}$ & Near highway, sloping area \\
\hline 6 & 23.03.2018 & $\begin{array}{l}\text { Budur, } \\
\text { Ağlasun }\end{array}$ & $\begin{array}{l}37^{\circ} 33^{\prime} 12^{\prime}, \mathrm{N} \\
30^{\circ} 31^{\prime} 8^{\prime}, \mathrm{E} \\
940 \mathrm{~m}\end{array}$ & Near highway, short pines \\
\hline 7 & 13.02.2018 & $\begin{array}{l}\text { Isparta, } \\
\text { Sütçüler }\end{array}$ & $\begin{array}{l}37^{\circ} 32^{\prime} 14^{\prime \prime}, \mathrm{N} \\
30^{\circ} 56^{\prime} 44^{\prime \prime} \mathrm{E} \\
1080 \mathrm{~m}\end{array}$ & $\begin{array}{l}\text { Sloping area, near marble } \\
\text { quarry }\end{array}$ \\
\hline 8 & 02.03 .2018 & $\begin{array}{l}\text { Antalya- } \\
\text { Kemer } \\
\text { highway }\end{array}$ & $\begin{array}{l}36^{\circ} 43^{\prime} 42^{\prime}, \mathrm{N} \\
30^{\circ} 33^{\prime} 23^{\prime}, \mathrm{E} \\
10 \mathrm{~m}\end{array}$ & $\begin{array}{l}\text { Near highway and urban } \\
\text { area, sparse pine forest }\end{array}$ \\
\hline 9 & 02.03 .2018 & $\begin{array}{l}\text { Beycik } \\
\text { Village, } \\
\text { Kemer }\end{array}$ & $\begin{array}{l}36^{\circ} 29^{\prime} 32^{\prime \prime} \mathrm{K} \\
30^{\circ} 26^{\prime} 11^{\prime \prime} \mathrm{D} \\
440-600 \mathrm{~m}\end{array}$ & Pine forest on a slope \\
\hline
\end{tabular}

Samplings were carried out at nine selected stations in the Western Mediterranean region during 2018. In February and March, nests containing last instar larvae of PPM were collected. Pupae were sampled in May and June. Eggs were collected in August and September.

At each station, one nest from each 15 pine trees infested with PPM was collected with the help of high branch pruning shears and taken to three-liter pet bins. The $30 \times 30$ $\mathrm{cm}$ cut tulles were stretched to the openings of the bins by using rubber for the insects can continue to breathe. The pupae were searched by digging pits at a depth of $20 \mathrm{~cm}$ at the bottom of the infested trees. The pupae were taken together with the soil in which they were placed and put in $1 \mathrm{~L}$ canisters. Eggs in cylindrical clusters on the young pine needles were plucked together with the leaves and kept in 1 L bins with tulle on their openings. Samples were brought to Süleyman Demirel University, Faculty of Arts and Sciences, Entomology Laboratory within the same day.

The larvae and nests of PPM larvae were kept in bins in the climate chamber at $25{ }^{\circ} \mathrm{C}$ and $55 \%$ humidity. In order to observe parasitoid emergence, larvae were conserved under suitable conditions. Therefore, in addition to establishing favorable conditions, the larvae were regularly fed with Pinus brutia needles. The collected pupae and egg clusters were also stored under the same conditions.

A predator coleopteran and a dermapteran species, which were observed to be fed by larvae in nests, prepared for identification. In addition, larva parasitoids (Diptera:Tachinidae) were sampled from the nests that brought to the laboratory and hymenopteran parasitoids were obtained from egg containers and kept for identification. Samples were sent to experts for identification. Also Chopard (1922), Jeannel (1941), Askew and Aldrey (2004) and Samra et al. (2018) were used as diagnostic keys.

\section{RESULTS}

During 2018, 24,660 larvae from 135 nests of Thaumetopoea wilkinsoni, 40 pupae and 58 egg clusters were sampled from nine stations. Some of the pupae mature under laboratory conditions. As a result, six species were determined as the natural enemies of Thaumetopoea wilkinsoni. One of them is Calosoma sycophanta (L., 1758), a natural predator of the PPM. Another potential 
predator species is Forficula smyrnensis Serville, 1839. Phryxe caudata (Róndani, 1859) is a larval parasitoid. Trichogramma Westwood, 1833 sp., Ooencyrtus pityocampae (Mercet, 1921) and Anastatus bifasciatus (Geoffroy, 1785) are egg parasitoids. No pupae parasitoid emergence was observed from 40 pupae collected.

\section{Calosoma sycophanta (L., 1758) (Coleoptera: Carabidae)}

Preys: Lymantria dispar L., L. monacha L., Dendrolimus pini L., Thaumetopoea processionea L., T. pityocampa (Denis ve Schiffermüller, 1775), T. wilkinsoni Tams, 1924, T. solitaria (Freyer, 1838), Euproctis chrysorrhoea L., Dasychira pudibunda L., Hyphantria cunea (Drury, 1773), Tortrix viridana L. (Weseloh, 1985; Mirchev and Tsankov, 2005; Kanat and Mol, 2008; Goertz and Hoch, 2013).

Geographical distribution: European countries, Western Palaearctic, Nearctic, Near East, Mid-Asia, Northern Africa (Kanat and Özbolat 2006; Stolbov et al., 2018).

\section{Forficula smyrnensis Serville, 1839 (Dermaptera: Forficulidae)}

Preys: According to some researchers, it is thought to be herbivorous, but other authors believe that it is omnivorous (plant material, aphids, spiders, insect eggs, dead insects) species like Forficula auricularia L. (Haas and Henderickx, 2002; Tezcan and Kocarek, 2009).

Geographical distribution: Turkey (terra typica), Albania, Bulgaria, Greece, Iran, Israel, Lebanon, Syria, former Yugoslavia (Albouy and Caussanel, 1990; Haas and Henderickx, 2002).

\section{Phryxe caudata (Róndani, 1859) (Diptera: Tachinidae)}

Hosts: Thaumetopoea pityocampa (Denis and Schiffermüller, 1775), Traumatocampa ispartaensis (Doğanlar and Avc1, 2001) (Pekel, 1999; Avc1 and Kara, 2002; Mirchev and Tsankov, 2005).

Geographical distribution: Mediterranean countries, Southern Europe and Northern Africa (Lutovinovas et al., 2018).

\section{Trichogramma sp. Westwood, 1833 (Hymenoptera: Trichogrammatidae)}

Hosts: Cydia pomonella L., Cydia molesta (Busck, 1916), Hedya nubiferana (Haw. 1811), Spilonota ocellana (Denis and Schiffermüller, 1775), Thaumetopoea pityocampa (Denis and Schiffermüller, 1775), T. processionea L., Archips Hubner, 1822 spp. (Mirchev and Tsankov, 2005; Öztemiz and., 2013).

Geographical distribution: Cosmopolitan (Buchori vd., 2010).

\section{Ooencyrtus pityocampae (Mercet, 1921) (Hymenoptera: Encyrtidae)}

Hosts: Stenozygum coloratum (Klug, 1845), Thaumetopoea pityocampa (Denis and Schiffermüller, 1775), $T$. wilkinsoni Tams, 1924, T. bonjeani (Powell, 1922) (Mirchev and Tsankov, 2005; Samra et al., 2018).

Geographical distribution: Eastern Mediterranean, Middle East ve Eastern Africa (Samra et al., 2018).

\section{Anastatus bifasciatus (Geoffroy, 1785) (Hymenoptera: Eupelmidae)}

Hosts: Thaumetopoea pityocampa (Denis and Schiffermüller, 1775), T. wilkinsoni Tams, 1924, T. processionea L., Lymantria dispar L. (Mirchev and Tsankov, 2005; Avc1, 2009).

Geographical distribution: Europe, Asia and Africa (Narendran, 2009).

Table 2 shows the number of sampled parasitoid and predator species in the studty stations.

Table 2. Sampled natural enemies in nine study stations.

\begin{tabular}{lccccccccc}
\hline Station & $\mathbf{1}$ & $\mathbf{2}$ & $\mathbf{3}$ & $\mathbf{4}$ & $\mathbf{5}$ & $\mathbf{6}$ & $\mathbf{7}$ & $\mathbf{8}$ & $\mathbf{9}$ \\
\hline $\begin{array}{l}\text { Ooencyrtus } \\
\text { pityocampae }\end{array}$ & - & - & 24 & 4 & $\begin{array}{l}1 \\
2\end{array}$ & $\begin{array}{l}1 \\
8\end{array}$ & - & $\begin{array}{l}3 \\
0\end{array}$ & - \\
\hline $\begin{array}{l}\text { Anastatus } \\
\text { bifascatus }\end{array}$ & - & - & 8 & 1 & - & - & - & - & - \\
\hline $\begin{array}{l}\text { Trichogram } \\
\text { ma sp. }\end{array}$ & - & - & 10 & 1 & - & - & - & - & - \\
\hline $\begin{array}{l}\text { Phryxe } \\
\text { caudata }\end{array}$ & 21 & 3 & 60 & 5 & 4 & 4 & - & 3 & 2 \\
\hline $\begin{array}{l}\text { Calosoma } \\
\text { sycophanta }\end{array}$ & 2 & 2 & 3 & 1 & - & - & - & - & - \\
\hline $\begin{array}{l}\text { Forficula } \\
\text { smyrnensis }\end{array}$ & - & - & - & - & - & - & - & 2 & - \\
\hline
\end{tabular}

The $3^{\text {rd }}$ station was determined to have the highest parasitoid density, while station 7 was the only area without natural enemies. This may be caused by antropogenic activities (marble mine) nearby. Nearly all Trichogramma individuals were sampled from $3^{\text {rd }}$ station. Forficula smyrnenis was sampled only from $8^{\text {th }}$ station. Percentages of individuals belonging to parasitoid and predator species were given in Figure 2. 


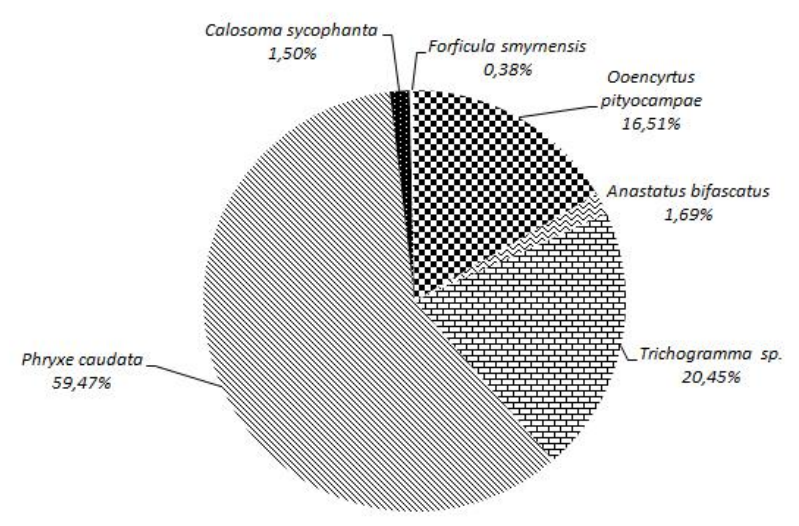

Figure 2. Percentages of individuals belonging to six natural enemy species.

The most frequent parasitoid species was Phryxe caudata $(59.47 \%)$ and was emerged from the eggs in all study stations except Number 7 .

\section{DISCUSSION AND CONCLUSIONS}

The PPM has a wide range of natural enemies in terms of predators and parasitoids. Six of them were sampled in this study. Mirchev and Tsankov (2005) published a checklist and according to this checklist natural enemies that recorded from Turkey are Ooencyrtus pityocampae, Baryscapus (Eutetrastichus) servadeii, B. (E.) transversalis, Anastatus bifasciatus and Trichogramma sp. In addition, tachinid parasitoids Exorista segregata and Phryxe caudata were found in Turkey by Pekel (1999) and Avc1 and Kara (2002). Ooencyrtus pityocampae is recorded by Mirschev et al. (2004) in southwestern Anatolia. Kanat and Mol (2008) stated that Calosoma sycophanta is used as an effective predator in the biological control of PPM in our country. In addition, Özçankaya and Can (2004) reported Forficula species in the PPM nests.

Calosoma sycophanta, which is frequently used in the biological control of this pest in Turkey (Kanat and Özbolat, 2006; Stolbov et al., 2018), is the first predator species obtained from field studies. Eight individuals from four areas were found. According to Mirchev and Tsankov (2005), this species is the larvae predator of the PPM. However, it is known to feed on pupa (Kanat and Özbolat 2006; Toprak, 2014). C. sycophanta larvae fed by another harmful lepidopteran Lymantria dispar L. pupa has been demonstrated by Weseloh (1985).

Another predator species found in this study is Forficula smyrnensis, sampled in Kemer, Antalya with two individuals. Özçankaya and Can (2004), found Forficula sp. individuals on the PPM nests. They reported that they did not observe the feeding event, so they could not comment on whether they were predators or not. But it was known that these insects were omnivorous and therefore fed with soft bodied insects. On the other hand, it was reported by Kailidis (1962) in Greece that Forficula auricularia was a PPM predator and listed as a predator on the check-list of Mirchev and Tsankov (2005). Haas and Hendrickx (2002), in their study of the intestinal contents of the collected dermapterans, found some plant materials in the gut of $F$. smyrnensis, so they speculate that the species may be herbivore contrary to its close relatives. However, Tezcan and Kocarek (2009) emphasized that such an interpretation cannot be made from the intestinal contents of a single individual and $F$. smyrnensis is most likely omnivorous like $F$. auricularia. For this reason, $F$. smyrnensis, sampled in a larval nest in Kemer during field surveys, could potentially be a PPM predator and it is recorded for the first time.

Phryxe caudata, which is one of the most common tachinid species in Turkey (Lutovinovas et al., 2018) is sampled from all study sites except $7^{\text {th }}$ station. Adults began to be observed in containers in which the nests were kept in the laboratory in June. Avc1 and Kara (2002) also stated that adults emerged in the second half of June. In terms of the number of individuals, this species was the most sampled with 317 individuals.

Trichogramma species are egg parasitoids of PPM (Mirchev and Tsankov, 2005) and in this study 109 individuals were collected. The members of this Hymenopteran genus cause taxonomic difficulties due to their small size and are difficult to identify (Nagarkatti and Nagaraja, 1977). Thus, Trichogramma specimens sampled in this study could not be identified to species level. But only two species ocur in Turkey, T. embryophagum and $T$. dendrolimi are parasitoids of PPM (Öztemiz et al., 2013), so the sampled specimens are likely to belong to one of these two species.

Ooencyrtus pityocampae is another hymenopteran egg parasitoid sampled in this study. Samra et al. (2018) determined that three species of Ooencyrtus (O. zoeae, O. telenomicida and $O$. pityocampae) are distributed in Turkey. They emphasized that $O$. pityocampae is a generalist parasitoid, using both Hemiptera and Lepidoptera members as hosts, and also one of the best known natural enemies of $T$. pityocampa and $T$. wilkinsoni in the Mediterranean Basin. In this study, 88 individuals of this species were collected.

Finally, hymenopteran egg parasitoid Anastatus bifasciatus was represented in this study with 9 individuals. Anastatus bifasciatus is listed on the chcklist of Mirchev and Tsankov (2005) and previously sampled in Turkey by Pekel (1990).

Results of this study may contribute to the literature on pest ecology, forestry and biological control efforts.

\section{ACKNOWLEDGEMENTS}

We thank to Assoc. Prof. Dr. Turgut ATAY from Tokat Gaziosmanpasa University, Faculty of Agriculture, Plant Protection Departmant for tachinid identification; Dr. Viktor FURSOV from Ukraine National Sciences Academy, Institute of Zoology for hymenopteran parasitoid identifications and Dr. Petr KOCAREK from Ostrava University, Department of Biology and Ecology for dermapteran identification. 


\section{REFERENCES}

Albouy, V., Caussanel, C. (1990). Dermaptères et perceoreilles. Thilliez, A. (Ed.) Faune de France No 75. Bulletin mensuel de la Société linnéenne de Lyon, 61(5), 117-118.

Askew, R.R., Nieves-Aldrey, J.L. (2004). Further observations on Eupelminae (Hymenoptera, Chalcidoidea, Eupelmidae) in the Iberian Peninsula and Canary Islands, including descriptions of new species. Graellsia, 60(1), 27-39.

Avc1, M., Kara, K. (2002). Tachinidae parasitoids of Traumatocampa ispartaensis from Turkey. Phytoparasitica, 30(4), 361-364.

Avc1, M. (2009). Parasitoid complex and new host plants of the gypsy moth, Lymantria dispar L. in the Lakes District, Turkey. Journal of Animal and Veterinary Advances, 8(7), 1402-1405.

Barbaro, L., Battisti, A. (2011). Birds as predators of the pine processionary moth (Lepidoptera: Notodontidae). Biological Control, 56, 107-114.

Battisti, A., Bernardi, M., Ghiraldo, C. (2000). Predation by the hoopoe on pupae of Thaumetopoea pityocampa and the likely influence on other natural enemies. Biocontrol, 45, 311-323.

Battisti, A., Avci, M., Avtzis, D.N., Ben Jamaa, M.L., Berardi, L., Berretima, W., Branco, M., Chakali, G., El Fels, M.A.A., Frérot, B., Hodar, J.A., IonescuMalancuş, I.I., İpekdal, K., Larsson, S., Manole, T., Mendel, Z., Meurisse, N., Mirchev, P., Nemer, N., Paiva, M.R., Pino, J., Protasov, A., Rahim, N., Rousselet, J., Santos, H., Sauvard, D., Schopf, A., Simonato, M., Yart, A., Zamoum, M. (2015). Natural history of the processionary moths (Thaumetopea spp.): New insights in relation to climate change. Roques, A. (Ed.) Processionary Moths and Climate Change: An Update. Editions Quæ, Versailles, France, 15-79.

Buchori, D., Meilin, A., Hidayat, P., Sahari, B. (2010). Species distribution of Trichogramma and Trichogrammatoidea genus (Trichogrammatoidea: Hymenoptera) in Java. Journal of International Society for Southeast Asian Agricultural Sciences, 16(1), 83-96.

Chopard, L. (1922). Fauna de France Vol. 3. Orthoptères et Dermaptères. Fédération Française des Sociétés de Sciences Naturelles, Paris, 212p.

Goertz, D. and Hoch, G. (2013). Influence of the forest caterpillar hunter Calosoma sycophanta on the transmission of Microsporidia in larvae of the gypsy moth Lymantria dispar. Agricultural and Forest Entomology, 15, 178-186.

Haas, F., Hendericx, H., (2002). Dermaptera from Cyprus and Turkey. Beitraege zur Entomologie Keltern, 52(1), 235-239.

Hodar, J.A., Zamora, R., Castro, J. (2002). Host utilisataion by moth and larval survival of pine processionary caterpillar Thaumetopoea pityocampa in relation to food quality in three Pinus species. Ecological Entomology, 27, 292-301.

İpekdal, K., Burban, C., Kerdelhue, C., Çağlar, S.S. (2015). Distribution of two pine processionary moth species in Turkey evidences a contact zone. Turkish Journal of Zoology, 39, 868-876.

Jansen, V.A.A., Sabelis, M.W. (1995). Outbreaks of colony-forming pests in tri-trophic systems: Consequences for pest control and the evolution of pesticide Resistance. Oikos, 74(1), 172-176.

Jeannel, R. (1941). Fauna de France Vol. 39. Coléoptères Carabiques. Fédération Française des Sociétés de Sciences Naturelles, Paris, 571p.

Kailidis, D. S. (1962). Bemerkungen über Thaumetopoea pityocampa Schiff. Und seine Feinde in Griechenland. Zeitschrift für Angewandte Entomologie, 51, 182-187.

Kanat, M., Özbolat, M. (2006). Mass production and release of Calosoma sycophanta L. (Coleoptera: Carabidae) used against the pine processionary moth, Thaumetopoea pityocampa (Schiff.) (Lepidoptera: Thaumetopoeidae), in biological control. Turkish Journal of Zoology, 30, 181-185.

Kanat, M., Mol, T. (2008). The effect of Calosoma sycophanta L. (Coleoptera: Carabidae) feeding on the pine processionary moth, Thaumetopoea pityocampa (Denis \& Schiffermüller) (Lepidoptera: Thaumetopoeidae), in the laboratory. Turkish Journal of Zoology, 32, 367-372.

Lamy, M. (1990). Contact-dermatitis (Erucism) produced by processionary caterpillars (Genus Thaumetopoea). Journal of Applied Entomology, 110, 425-437.

Lewis, W.J., van Lenteren, J.C., Phatak, S.C., Tumlinson, J.H. (1997). A total system approach to sustainable pest management. Proceedings of the National Academy of Sciences, 94, 12243-12248.

Lutovinovas, E., Tschorsnig, H.P., Barták, M., Kubík, Š., Dursun, O., Civelek, H.S., Kara, K. (2018). Contribution to the tachinid fauna of Southwestern Turkey (Diptera: Tachinidae). Annales de la Société entomologique de France, 54(4), 1-31.

Mirchev, P., Schmidt, G.H., Tsankov, G., Avci, M. (2004). Egg parasitoids of Thaumetopoea pityocampa (Den. \& Schiff.) (Lep., Thaumetopoeidae) and their impact in SW Turkey. Journal of Applied Entomology, 128(8), 533-542.

Mirchev, P., Tsankov, G. (2005). Checklist of the parasitoids and predators of Thaumetopoea spp. (Lepidoptera: Notodontidae). Acta Entomologica Bulgarica, 11, 82-96.

Nagarkatti, S., Nagaraja, H. (1977). Biosystematics of Trichogramma and Trichogrammatoidea species. Annual Review of Entomology, 22, 157-76. 
Narendran, T.C. (2009). A Review of the species of Anastatus Motschulsky (Hymenoptera: Chalcidoidea: Eupelmidae) of the Indian Subcontinent. Journal of Threatened Taxa, 1(2), 7296.

Özçankaya, İ.M., Can, P. (2004). Muğla ili kızılçam sğaçlandırma alanlarında çam keseböceği (Thaumetopoea pityocampa (Den. \& Schiff.)(Lep., Thaumetopoeidae))'nin mekanik ve biyolojik savaş olanaklarının geliştirilmesi üzerine araştırmalar. T.C. Çevre ve Ormancılık Bakanlığı Ege Ormancılık Araştırma Müdürlüğü, Bülten No: 26, 84s.

Öztemiz, S., Sümer Ercan, F., Tunçbilek, A.Ş. (2013). Türkiye'de Trichogramma (Hymenoptera: Trichogrammatidae) türleri, konukçuları ve sistematiğindeki son gelişmeler. Erciyes Üniversitesi Fen Bilimleri Enstitüsü Dergisi, 29(3), 240-246.

Pekel, N. (1999). Isparta Orman Bölge Müdürlüğü ormanlarında çam kese böceği Thaumetopoea pityocampa (Den. \& Schiff.)'nin biyolojisi ve tabii düşmanlarının araştırılması. Süleyman Demirel Üniversitesi, Yüksek Lisans Tezi, 58s, Isparta.

Samra, S., Cascone, P., Noyes, J., Ghanim, M., Protasov, A., Guerrieri, E., Mendel, Z. (2018). Diversity of Ooencyrtus spp. (Hymenoptera: Encyrtidae) parasitizing the eggs of Stenozygum coloratum (Klug) (Hemiptera: Pentatomidae) with description of two new species. Plos One, 13(11), 1-23.

Stiling, P., Cornelissen, T. (2005). What makes a successful biocontrol agent? A metaanalysis of biological control agent performance. Biological Control, 34, 236-246.

Stolbov, V.A., Kuzmin, I.V., Lomakin, D.E., Ivanov, S.A., Sitnikov, P.S. (2018). New records and range expansion of Calosoma sycophanta (Linnaeus, 1758) (Coleoptera, Carabidae) in Western Siberia, Russia. Check List, 14(5), 731-736.
Tezcan, S., Kocarek, P. (2009). Dermaptera fauna of the ecologically managed cherry orchards in western Turkey. Munis Entomology \& Zoology Journal, 4(2), 572-576.

Toprak, Ö. (2014). Mass production of Calosoma sycophanta (L.) in the integrated fighting against the pine processionary moth (Thaumetopoea pityocampa Schiff.). 2nd Symposium of Turkey Forest Entomology and Pathology Symposium, 7-9 Nisan, Antalya, p. 349-360.

Tsankov, G. (1990). Egg parasitoids of the pine processionary moth, Thaumetopoea pityocampa (Den. \& Schiff.) (Lep., Thaumetopeidae) in Bulgaria: Species, importance, biology and behaviour. Jounal of Applied Entomology, 110, 713.

Tsankov, G., Douma-Petridou, E., Mirchev, P., Georgiev, G., Koutsaftikis, A. (1999). Spectrum of egg parasitoids and rate of parasitism of egg batches of the pine processionary moth Thaumetopoea pityocampa (Den. \& Schiff.) in the Northern Peloponnes/Greece. Journal of the Entomological Research Society, 1(2), 1-8.

Way, M.J., Paiva, M.R., Cammell, M.E. (1999). Natural biological control of the pine processionary moth Thaumetopoea pityocampa (Den. \& Schiff.) by the Argentine ant Linepithema humile (Mayr) in Portugal. Agricultural and Forest Entomology, 1, 2731.

Weseloh, R.M. (1985). Predation by Calosoma sycophanta L. (Coleoptera: Carabidae): Evidence for a large impact on gypsy moth, Lymantria dispar L. (Lepidoptera: Lymantriidae), pupae. The Canadian Entomologist, 117, 1117-1126.

Ziprkowski, L., Roland, F. (1966). Study of the toxin from the poison hairs of Thaumetopoea wilkinsoni caterpillars. Journal of Investigative Dermatology, 46, 439-445. 